\title{
Wheat Cultivar-Specific Disease Synergism and Alteration of Virus Accumulation During Co-Infection with Wheat streak mosaic virus and Triticum mosaic virus
}

\author{
Satyanarayana Tatineni, Robert A. Graybosch, Gary L. Hein, Stephen N. Wegulo, and Roy French
}

\begin{abstract}
First and fifth authors: United States Department of Agriculture-Agriculture Research Service (USDA-ARS) and Department of Plant Pathology, second author: USDA-ARS and Department of Agronomy and Horticulture, third author: Department of Entomology, and fourth author: Department of Plant Pathology, University of Nebraska-Lincoln, Lincoln 68583.

Accepted for publication 11 December 2009.
\end{abstract}

\begin{abstract}
Tatineni, S., Graybosch, R. A., Hein, G. L., Wegulo, S. N., and French, R. 2010. Wheat cultivar-specific disease synergism and alteration of virus accumulation during co-infection with Wheat streak mosaic virus and Triticum mosaic virus. Phytopathology 100:230-238.

Triticum mosaic virus (TriMV), the type member of the newly proposed Poacevirus genus, and Wheat streak mosaic virus (WSMV), the type member of Tritimovirus genus of the family Potyviridae, infect wheat naturally in the Great Plains and are transmitted by wheat curl mites. In this study, we examined the ability of these viruses to infect selected cereal hosts, and found several differential hosts between TriMV and WSMV. Additionally, we examined the interaction between WSMV and TriMV in three wheat cultivars at two temperature regimens (19 and 20 to $26^{\circ} \mathrm{C}$ ), and quantified the virus concentration in single and double infections by real-time reverse-transcription polymerase chain reaction. Double infections in wheat cvs. Arapahoe and Tomahawk at both tem-

perature regimens induced disease synergism with severe leaf deformation, bleaching, and stunting, with a 2.2- to 7.4-fold increase in accumulation of both viruses over single infections at 14 days postinoculation (dpi). However, at $28 \mathrm{dpi}$, in double infections at 20 to $26^{\circ} \mathrm{C}$, TriMV concentration was increased by 1.4- to 1.8-fold in Arapahoe and Tomahawk but WSMV concentration was decreased to 0.5-fold. WSMV or TriMV replicated poorly in Mace at $19^{\circ} \mathrm{C}$ with no synergistic interaction whereas both viruses accumulated at moderate levels at 20 to $26^{\circ} \mathrm{C}$ and induced mild to moderate disease synergism in doubly infected Mace compared with Arapahoe and Tomahawk. Co-infections in Mace at 20 to $26^{\circ} \mathrm{C}$ caused increased TriMV accumulation at 14 and 28 dpi by 2.6- and 1.4-fold and WSMV accumulated at 0.5- and 1.6-fold over single infections, respectively. Our data suggest that WSMV and TriMV induced cultivar-specific disease synergism in Arapahoe, Tomahawk, and Mace, and these findings could have several implications for management of wheat viruses in the Great Plains.
\end{abstract}

Among viruses infecting wheat (Triticum aestivum L.) in the Great Plains of the United States, Wheat streak mosaic virus (WSMV) is one of the economically important viruses causing significant yield losses $(3,6)$. Recently, a new wheat virus, Triticum mosaic virus (TriMV), was found in Kansas and Nebraska $(20,29)$. WSMV, the type member of the genus Tritimovirus in the family Potyviridae, has been relatively well studied (3,5,24-26). In contrast, TriMV was recently reported (20), and its genome sequence has revealed that it is a member of the family Potyviridae. However, TriMV encodes mature proteins bearing only 18 to $41 \%$ amino acid identity with the corresponding proteins of WSMV (29). Based on limited sequence homology of TriMV proteins with representative genera of Potyviridae, a new genus, Poacevirus, has been proposed, with TriMV as the type member (29); however, little is known of the biology of this virus in relation to its host range and extent of differences from WSMV.

Field surveys conducted throughout the Great Plains in 2008 revealed that TriMV was prevalent in the region, being found in $17 \%$ of 754 tested samples whereas, not surprisingly, WSMV was detected in $47 \%$ of the samples (4). In all, $43 \%$ of symptomatic

Corresponding author: S. Tatineni

E-mail address: Satyanarayana.tatineni@ars.usda.gov

* The $e$-Xtra logo stands for "electronic extra" and indicates that Figure 1 appears in color online.

doi:10.1094/PHYTO-100-3-0230

This article is in the public domain and not copyrightable. It may be freely reprinted with customary crediting of the source. The American Phytopathological Society, 2010. wheat samples submitted in 2009 to the University of NebraskaLincoln Plant and Pest Diagnostic Clinic reacted positively for TriMV while $15 \%$ of wheat samples were positive for WSMV (S. N. Wegulo, unpublished). Symptoms of wheat infected with TriMV are similar to those of WSMV-infected wheat under field conditions $(4,20)$. However, the economic impact of TriMV on wheat production is not yet known. Both WSMV and TriMV are vectored by Aceria tosichella Keifer, the wheat curl mite $(19,21)$, leading to reasonable expectation that double infections will occur. Indeed, a recent Great Plains wheat virus survey indicated that $13 \%$ of samples tested were positive for double infection with WSMV and TriMV, while the incidence of double infections in Kansas in 2006 was nearly 60\% (4,20). The potential for interactions between these two viruses that affect crop yield and quality clearly needs to be investigated.

Disease synergism is defined as induction of more severe symptoms due to co-infection of two (usually unrelated) viruses than symptoms induced by the individual viruses separately (9). Often, the titer of one or both viruses also increases in co-infections $(1,2,7,17,27,30)$. The degree of synergism can vary depending on host species (31) or even host plant cultivar (28). WSMV and TriMV naturally infect wheat but there is no information on whether co-infection with these two viruses causes disease synergism in wheat or whether any differences exist among wheat cultivars in their reaction to single and double infections with these viruses. Of particular interest is the WSMV-resistant cv. Mace, which carries resistance or tolerance conditioned by the Wsm-1 gene, introgressed to wheat from Thinopyrum intermedium (Host) Barkworth \& Dewey, and was released in 2008 (8). Because TriMV occurs in both single infections and double 
infections with WSMV, it is important to determine the effects of infection of Mace by TriMV alone and in combination with WSMV.

In this study, we examined the experimental host range of TriMV by inoculating a range of agronomically important cereal species. We further studied the interaction between WSMV and TriMV in three wheat cultivars-Arapahoe, Tomahawk, and Mace - in two environments $\left(19^{\circ} \mathrm{C}\right.$ [growth chamber] and 20 to $26^{\circ} \mathrm{C}$ [greenhouse]), examining symptom expression and synergistic interactions. We determined virus concentrations in single and double infections using real-time reverse-transcription (RT) polymerase chain reaction (PCR).

\section{MATERIALS AND METHODS}

Virus isolates. WSMV Sidney 81 isolate was obtained from an infectious cDNA clone, whose in vitro-generated RNA transcripts were inoculated to wheat seedlings at the single-leaf stage (5). A Nebraska isolate of TriMV was activated from dried wheat leaves that were stored at $4^{\circ} \mathrm{C}$ in a $125-\mathrm{ml}$ Erlenmeyer flask containing anhydrous calcium sulfate (29). Wheat seedlings at the single-leaf stage were inoculated with WSMV Sidney 81 or with TriMV 10 days before inoculation of experimental plants to obtain a fresh source of inoculum.

Host range. WSMV or TriMV in crude sap at 1:20 dilution in $20 \mathrm{mM}$ sodium phosphate buffer, $\mathrm{pH} 7.0$ (inoculation buffer), was used to mechanically inoculate 15 to 35 carborundum-dusted seedlings that were 7 to 10 days old (Table 1). Inoculated plants were maintained in a greenhouse with $26^{\circ} \mathrm{C}$ maximum and $20^{\circ} \mathrm{C}$ minimum temperatures with $14 \mathrm{~h}$ of daylight or supplemental light and were examined for symptom development at 7 to 25 days postinoculation (dpi). The inoculated plants were tested by realtime RT-PCR using WSMV- or TriMV-specific primers or probes (see below).
Infection of wheat cultivars with WSMV, TriMV, or both. Young wheat leaves infected with WSMV or TriMV at 10 to 12 dpi were ground in inoculation buffer $(1 \mathrm{~g}$ per $9 \mathrm{ml})$ with a mortar and pestle, and the inocula were mixed at a 1:1 ratio to obtain 1:20 dilution of WSMV plus TriMV inoculum. The WSMV or TriMV inoculum was also diluted 1:1 with inoculation buffer to obtain the final dilution of 1:20. Pasteurized soil mix which consisted of $33 \%$ each of clay loam soil and peat moss, and $16.5 \%$ each of sand and vermiculite was used to raise wheat plants. Carborundum-dusted wheat cvs. Arapahoe, Tomahawk, and Mace at the single-leaf stage were mechanically inoculated with WSMV or TriMV or WSMV plus TriMV (20 seedlings per 6 -in. earthen pot), and three pots per cultivar were incubated in the greenhouse at $26^{\circ} \mathrm{C}$ maximum and $20^{\circ} \mathrm{C}$ minimum temperatures with $\approx 14 \mathrm{~h}$ of daylight or supplemental light. Another set of inoculated wheat seedlings was incubated in a growth chamber at $19^{\circ} \mathrm{C}$ with $14 \mathrm{~h}$ of light per day. Wheat plants were observed for symptom development daily from 5 dpi onward and leaf pictures were taken at 14 and $28 \mathrm{dpi}$. Cultural practices were followed to control mite population in the greenhouse and, during the course of this experiment, uninoculated wheat plants remained virus free.

Isolation of total RNA. Tissue $(200 \mathrm{mg})$ from fully expanded upper leaves of wheat plants infected with WSMV, TriMV, WSMV plus TriMV, or healthy plants was ground in liquid nitrogen into a fine powder; $1 \mathrm{ml}$ of TriPure isolation reagent (Roche, Indianapolis, IN) was added; and the tissue was ground thoroughly. The extract was transferred to a 2.0-ml Eppendorf tube, $0.25 \mathrm{ml}$ of chloroform was added, and the tube was vortexed for $30 \mathrm{~s}$. This mixture was incubated at room temperature for $10 \mathrm{~min}$, followed by clarification at $12,000 \times g$ for $15 \mathrm{~min}$ at $4^{\circ} \mathrm{C}$. The total RNA was precipitated from $200 \mu \mathrm{l}$ of the aqueous phase by adding an equal volume of isopropanol and incubated at room temperature for $10 \mathrm{~min}$. The RNA was pelleted at $12,000 \times g$ for $10 \mathrm{~min}$ at $4{ }^{\circ} \mathrm{C}$, and the pellet was washed with $500 \mu \mathrm{l}$ of $70 \%$ ethanol. A

TABLE 1. Comparative host range of Triticum mosaic virus and Wheat streak mosaic virus on selective host plants ${ }^{\mathrm{a}}$

\begin{tabular}{|c|c|c|c|c|}
\hline \multirow[b]{2}{*}{ Host } & \multicolumn{2}{|c|}{ Triticum mosaic virus } & \multicolumn{2}{|c|}{ Wheat streak mosaic virus } \\
\hline & Local & Systemic & Local & Systemic \\
\hline Avena sativa L. cv. Cherokee & - & SI & - & MMO, MMTL \\
\hline A. sativa L. cv. Proat & - & SI & - & MMO, MMTL \\
\hline Hordeum vulgare L. cv. Baronese & - & MO, CS, MTL, LNC (10/27) & $\mathrm{CS}, \mathrm{CST}$ & - \\
\hline H. vulgare L. cv. Geraldine & - & $\mathrm{CST}, \mathrm{CS}, \mathrm{MO}$ & CST & - \\
\hline H. vulgare L. cv. Harrington & - & CST, MO, MTL & CS & CST, MO, MTL \\
\hline Pennisetum glaucum L. R. Br. line NM5B & - & - & - & - \\
\hline Sorghum bicolor L. line KS56 & - & - & LNS & - \\
\hline S. bicolor L. line 8585 & - & - & LNS & - \\
\hline S. bicolor L. line 8686 & - & - & LNS & - \\
\hline S. bicolor L. line Bug off & - & - & LNS & - \\
\hline Secale cereale L. cv. Merced & - & MMO,MTL (4/15) & - & - \\
\hline S. cereale cv. Petkus & - & CST, MO, MTL (7/15) & - & CST, CS, MO (7/16) \\
\hline Triticale, line NT 01451 & - & CST, CS, CLP (22/24) & - & CST, CLP $(2 / 16)$ \\
\hline Triticale, line NT02421 & - & CST, CS, CLP (17/25) & - & CST, MO, CLP (24/27) \\
\hline Triticale, line NE03T416 & - & MO, CLP, MTL (30/35) & - & CST, CS, CLP $(24 / 28)$ \\
\hline Zea mays L. line SDp2 & - & - & - & $\mathrm{CS}, \mathrm{CST}, \mathrm{MO}, \mathrm{VB}$ \\
\hline Z. mays L. line Spirit & - & - & - & - \\
\hline Z. mays L. line MO17 × B73 & - & - & - & - \\
\hline
\end{tabular}

${ }^{\text {a }}$ In all, 15 to 35 seedlings were inoculated per host in two independent experiments and inoculated plants were incubated in a greenhouse at 20 to $26^{\circ} \mathrm{C}$ with $14 \mathrm{~h}$ of daylight. Symptoms were evaluated at 7 and 14 days postinoculation on inoculated and noninoculated leaves, respectively. All inoculated plants were infected unless the number of plants infected/number of plants inoculated is indicated in parenthesis or a dash is used to indicate that no plants were infected. CLP: chlorotic line pattern; CS: chlorotic spots; CST: chlorotic streaks, LN: leaf narrowing; LNC: leaf necrosis; LNS: local necrotic streaks; MCS: mild chlorotic spots; MO: mosaic; MMO: mild mosaic; MTL: mottling; MMTL: mild mottling; SI: symptomless infection; VB: vein banding; VC: veinal chlorosis; VY: vein yellowing. 
vacuum-dried RNA pellet was suspended in $125 \mu \mathrm{l}$ of sterile water and stored frozen at $-70^{\circ} \mathrm{C}$. The amount of total RNA was quantified using a NanoPhotometer (Implene Inc., Westlake Village, CA).

First-strand cDNA synthesis. Total RNA $(1 \mu \mathrm{g})$ extracted from healthy wheat leaves or infected with WSMV, TriMV, or WSMV plus TriMV was used to synthesize the first-strand cDNA in a 20- $\mu$ reaction volume in the presence of $1 \times$ first-strand reaction buffer, $400 \mu \mathrm{M}$ dNTPs, random primers (Promega Corp., Madison, WI) at $2.5 \mathrm{ng} / \mu \mathrm{l}$, and $8.8 \mathrm{U}$ of AMV reverse transcriptase (Roche) at $42^{\circ} \mathrm{C}$ for $60 \mathrm{~min}$ followed by $5 \mathrm{~min}$ of incubation at $95^{\circ} \mathrm{C}$. Then, $1 \mu \mathrm{l}$ of $1: 10$ diluted first-strand cDNA was used for the real-time PCR reaction in a $25-\mu \mathrm{l}$ volume (see below).

Real-time RT-PCR. The primers and probes for absolute quantification of WSMV and TriMV by real-time PCR were selected by analyzing the coat protein nucleotide sequences by the Real-time PCR Design Tools of Integrated DNA Technologies Inc. (Coralville, IA). The sequence and nucleotide coordinates of primers and probes are given in Table 2.

Real-time PCR was performed with Applied Biosystems 7300 Real-Time PCR System (Foster City, CA) using primers and probes specific to WSMV or TriMV (Integrated DNA Technologies), and TaqMan DNA polymerase (Applied Biosystems) in a $25-\mu l$ reaction. The primers and probes specific to either WSMV or TriMV were used at 500 and $250 \mathrm{nM}$, respectively. The standard amplification protocol was at $50^{\circ} \mathrm{C}$ for 2 min and $95^{\circ} \mathrm{C}$ for $15 \mathrm{~min}$, followed by 40 cycles at $95^{\circ} \mathrm{C}$ for $15 \mathrm{~s}$ and $58^{\circ} \mathrm{C}$ for $60 \mathrm{~s}$. All reactions were performed in duplicate or triplicate with primers and probes for the detection of WSMV or TriMV and 18S RNA. Each run included cDNA synthesized from the total RNA extracted from WSMV- or TriMV-infected plants as a positive control and total RNA from healthy wheat leaves and water as negative controls and three dilutions of the standard curve. The 18S RNA was used as an internal reference gene, and primers and probes were used at 50 and $200 \mathrm{nM}$, respectively, as per the instructions (Applied Biosystems). The oligonucleotide probes of WSMV and TriMV were labeled with 6-FAM and the probe for 18S RNA was labeled with VIC.

The DNA template used to make a standard curve was converted into picomoles based on average molecular weight of a deoxyribonucleotide $(330 \mathrm{Da})$ and the number of bases in the DNA using the following formula: micrograms of doublestranded DNA $\times\left(10^{6}\right.$ pg per $\left.1 \mu \mathrm{g}\right) \times(1$ pmol per $660 \mathrm{pg}) \times(1$ per number of bases of DNA) $\times$ Avogadro constant $\left(6.023 \times 10^{23}\right.$ molecules/mol). The agarose-gel-purified PCR fragments ( $1 \mu \mathrm{g}$ in $20 \mu \mathrm{l})$ were diluted serially in water $\left(10^{-3}\right.$ to $\left.10^{-10}\right)$ to develop a standard curve for absolute quantification of genomic RNA copies of WSMV or TriMV.

Absolute quantification of genomic RNA copies. The absolute number of genomic RNA copies of WSMV or TriMV in single and double infections of wheat cultivars was calculated from the threshold cycle $(\mathrm{Ct})$ values of real-time RT-PCR using Q-Gene software $(10,12)$. The normalized expression of the target gene (WSMV or TriMV) from each sample was calculated based on the $\mathrm{Ct}$ value of $18 \mathrm{~S}$ RNA of the corresponding sample. Differences between normalized expression levels of WSMV or TriMV in double infections versus single infections were tested for statistical significance by 5,000 permutations of the data using the computer program REST (13).

\section{RESULTS}

Host range of TriMV. TriMV was reported as one of the naturally infecting viruses of wheat $(20,29)$ but there is limited information on the ability of this virus to infect other agronomically important cereal species. In this study, we examined the ability of TriMV to infect a range of cereal species by mechanical inoculation with crude sap from TriMV-infected wheat leaves and compared it with that of WSMV under the same experimental conditions. Comparative symptoms induced by TriMV and WSMV on various hosts are presented in Table 1.

All tested wheat cultivars, triticale ( $\times$ Triticosecale Wittmack) lines, Secale cereale L. cv. Petkus, and Hordeum vulgare L. cvs. Harrington, Hockett, and Metcalfe were common hosts for TriMV and WSMV (Table 1). However, we found several differential hosts between the two viruses. TriMV induced systemic chlorotic streaks or spots, mosaic, and mottling symptoms on $H$. vulgare cvs. Baronese and Geraldine and $S$. cereale cv. Merced, whereas WSMV failed to infect these hosts under the same conditions (Table 1; Fig. 1). In contrast, WSMV induced systemic chlorotic streaks or spots, mosaic, and vein banding symptoms on Zea mays L. line SDp2 but TriMV failed to infect it (Table 1; Fig. 1). Sorghum bicolor (L.) Moench lines responded to WSMV infection with a hypersensitive reaction by producing local necrotic streaks and failed to develop systemic symptoms, whereas TriMV failed to induce either local or systemic symptoms (Table 1; Fig. 1). WSMV induced mild mosaic and mottling symptoms on Avena sativa L. cvs. Cherokee, Proat, and Shaw, and TriMV induced symptomless infection on these hosts (Table 1). Both WSMV and TriMV failed to infect Pennisetum glaucum L. R. Br. line NM5B and Z. mays lines Spirit (a sweet corn hybrid) and MO17XB73 (a field corn breeding line) (Table 1).

Symptom expression in single or double infections in wheat cvs. Arapahoe, Tomahawk, and Mace. We examined whether WSMV and TriMV would interact synergistically upon coinfection of wheat cvs. Arapahoe, Tomahawk, and Mace at $19^{\circ} \mathrm{C}$ (growth chamber) and 20 to $26^{\circ} \mathrm{C}$ (greenhouse). Infection of wheat cultivars by WSMV, TriMV, or WSMV plus TriMV was examined by RT-PCR. Wheat cultivars tested positive for WSMV or TriMV only when they had been inoculated with the respective virus (data not shown). As expected, plants inoculated with a mixture of WSMV and TriMV contained both viruses. The RTPCR amplification from WSMV- or TriMV-infected wheat plants resulted in 1,150- and 1,050-bp products with WSMV- and TriMV-specific primers, respectively (data not shown).

Symptoms at 20 to $26^{\circ} \mathrm{C}$. WSMV and TriMV induced systemic chlorotic streaks and spots on wheat cvs. Arapahoe and Tomahawk by 5 and $7 \mathrm{dpi}$, respectively, followed by chlorotic stripes, mosaic, and mottling symptoms with slight stunting of

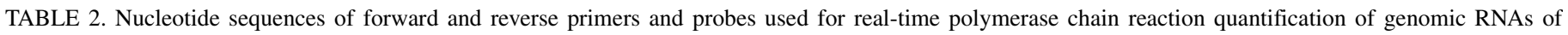
Triticum mosaic virus (TriMV) and Wheat streak mosaic virus (WSMV)

\begin{tabular}{|c|c|c|}
\hline Primer & Nucleotide sequence $\left(5^{\prime}-3^{\prime}\right)$ & Position \\
\hline TriMV-F & CTTTGGAGCTTTAGCCTACC & $9,754-9,773^{\mathrm{a}}$ \\
\hline TriMV-R & CTGGTCCACTGTCACAAA & $9,875-9,892$ \\
\hline TriMV-Probe & CAAGCCAATTATACCGCACAACGC & $9,802-9,825$ \\
\hline WSMV-F & AAGTGCAGAACAGCGTTG & $9,075-9,092^{\mathrm{b}}$ \\
\hline WSMV-R & AAACTGTGCGTGTTCTCC & $9,196-9,213$ \\
\hline WSMV-Probe & ACTGAGTGCGGGTACTAATGAGGAC & $9,142-9,166$ \\
\hline
\end{tabular}

a Nucleotide positions correspond to the genomic RNA sequence of TriMV (GenBank accession no. FJ669487).

b Nucleotide positions correspond to the genomic RNA sequence of WSMV (GenBank accession no. NC_001886). 
plants by 14 dpi. By 28 dpi, WSMV induced long chlorotic stripe or line patterns with mosaic, mottling, and mild leaf deformation symptoms in Arapahoe (Fig. 2A, a2), while Tomahawk displayed similar symptoms without leaf deformation (Fig. 2A, b2). TriMV induced mosaic or mottling with large chlorotic streaks in Arapahoe and Tomahawk by 28 dpi (Fig. 2A, a3, b3). In general, symptoms induced by TriMV on Arapahoe and Tomahawk were milder than those induced by WSMV. Interestingly, WSMV and TriMV induced chlorotic streaks on Mace at 6 and 14 dpi, respectively, and some chlorotic streaks enlarged into chlorotic patches by 14 to $28 \mathrm{dpi}$. Symptoms induced by TriMV on Mace were delayed by 7 to 9 days compared with WSMV but, in prolonged infections, both viruses induced chlorotic streaks and patches with slightly milder symptoms by TriMV (Fig. 2A, c2, c3).

Co-infection of Arapahoe and Tomahawk with WSMV and TriMV induced chlorotic streaks and spots by 5 to 6 dpi and subsequently resulted in a synergistic interaction by 14 to $18 \mathrm{dpi}$ with stunting and narrowing of leaves, with some leaves exhibiting a bleaching effect with severe chlorosis. Arapahoe with double infections displayed severe leaf deformation with scaly leaves, leaf curling with mosaic, and mottling by 18 to $28 \mathrm{dpi}$ (Fig. 2A, a4). Leaf deformation in doubly infected Tomahawk was not as severe as in Arapahoe but the leaves, particularly noninoculated leaves just above inoculated leaves, showed a bleaching effect with mosaic and mottling, and resulted in overall stunting of plants (Fig. 2A, b4). Mace plants inoculated with WSMV and TriMV developed a few chlorotic streaks by 8 dpi, followed by several chlorotic streaks per leaf, which became coalesced into chlorotic patches by $18 \mathrm{dpi}$. By $28 \mathrm{dpi}$, double infections in Mace induced mild to moderate symptoms when compared with Arapahoe and Tomahawk, with enlarged chlorotic streaks, leaf chlorosis, and mild stunting (Fig. 2A, c4).

Symptoms at $19^{\circ} \mathrm{C}$. In general, symptoms induced at $19^{\circ} \mathrm{C}$ were slightly milder than at 20 to $26^{\circ} \mathrm{C}$ (Fig. 2, compare panels A and B). WSMV or TriMV induced chlorotic streaks on Arapahoe and Tomahawk by 6 to $8 \mathrm{dpi}$, which later turned into chlorosis and mosaic by 11 to 14 dpi. Both cultivars developed mild mosaic, mottling, chlorotic line patterns, and chlorotic streaks or spots by 28 dpi with WSMV or TriMV infection (Fig. 2B, a2, a3, b2, b3). WSMV or TriMV induced mild symptoms on Mace with a few chlorotic streaks at 14 to 28 dpi (Fig. 2B, c2, c3).

Double infections in Arapahoe and Tomahawk induced severe chlorotic streaks at $6 \mathrm{dpi}$ and, later, induced severe yellowing of leaves, mosaic, mottling, and bleaching by 14 to 28 dpi (Fig. 2B, a4, b4). However, doubly infected Mace exhibited a few chlorotic streaks by 14 dpi and there was no increase in symptom severity compared with single infections even at $28 \mathrm{dpi}$ (Fig. 2B, c4).

The real-time RT-PCR method for absolute quantification of WSMV and TriMV. Initially, we tested the combination of primers and probes for 18S RNA and WSMV or TriMV in a single reaction (multiplex reaction), which resulted in higher $\mathrm{Ct}$ values than independently performed reactions (data not shown). Therefore, in subsequent experiments, we performed independent reactions with primers and probes specific to WSMV, TriMV, or 18S RNA. We also compared the total RNA extracted by the TriPure isolation reagent method as described in the methods section with the total RNAs further purified by phenol:chloroform extraction, followed by ethanol precipitation. The cDNAs from the total RNAs isolated by both of these methods resulted in similar Ct values; therefore, we used the total RNAs isolated by the TriPure isolation reagent in real-time PCR reactions. We further examined the specificity of primers and probes by including the gel-purified PCR product of WSMV and TriMV, which was used to generate standard curves (see below) for each primerprobe combination. The primer-probes did not cross hybridize with the heterologous template (Fig. 3), indicating that the primers and probes for WSMV and TriMV are specific.
The number of genomic RNA copies of WSMV and TriMV were calculated from the standard curves developed for the gelpurified PCR product as the template. A standard curve was developed using gel-purified PCR fragments amplified from the genomic regions: nucleotides 8,483 to 9,407 for WSMV and 9,254 to 10,267 for TriMV. The gel-purified PCR fragments were quantified using a NanoPhotometer (Implene Inc.). We attempted to prepare standard curves for WSMV and TriMV using the cDNA synthesized from RNase free-RQ DNase-treated in vitro transcripts generated from gel-purified PCR products. However, in repeated attempts, we failed to obtain similar quality RNA transcripts for WSMV and TriMV. Hence, to minimize the error in the quality difference between the RNA preparations of WSMV and TriMV, we used an agarose-gel-purified PCR fragment as the template to generate standard curves (Fig. 3A, B). The standard curves for WSMV and TriMV were generated using 10-fold serial dilution of gel-purified PCR fragments from $4.9 \times 10^{7}$ and $4.5 \times$ $10^{7}$ molecules, respectively.

The standard curves for WSMV and TriMV covered 8 log units of concentration and showed a strong linear relationship $\left(R^{2}\right.$ values of 0.9961 and 0.9985 for WSMV and TriMV, respectively) with amplification efficiencies $>90 \%$ (Fig. 3). The slope values for WSMV and TriMV standard curves were -3.6614 and
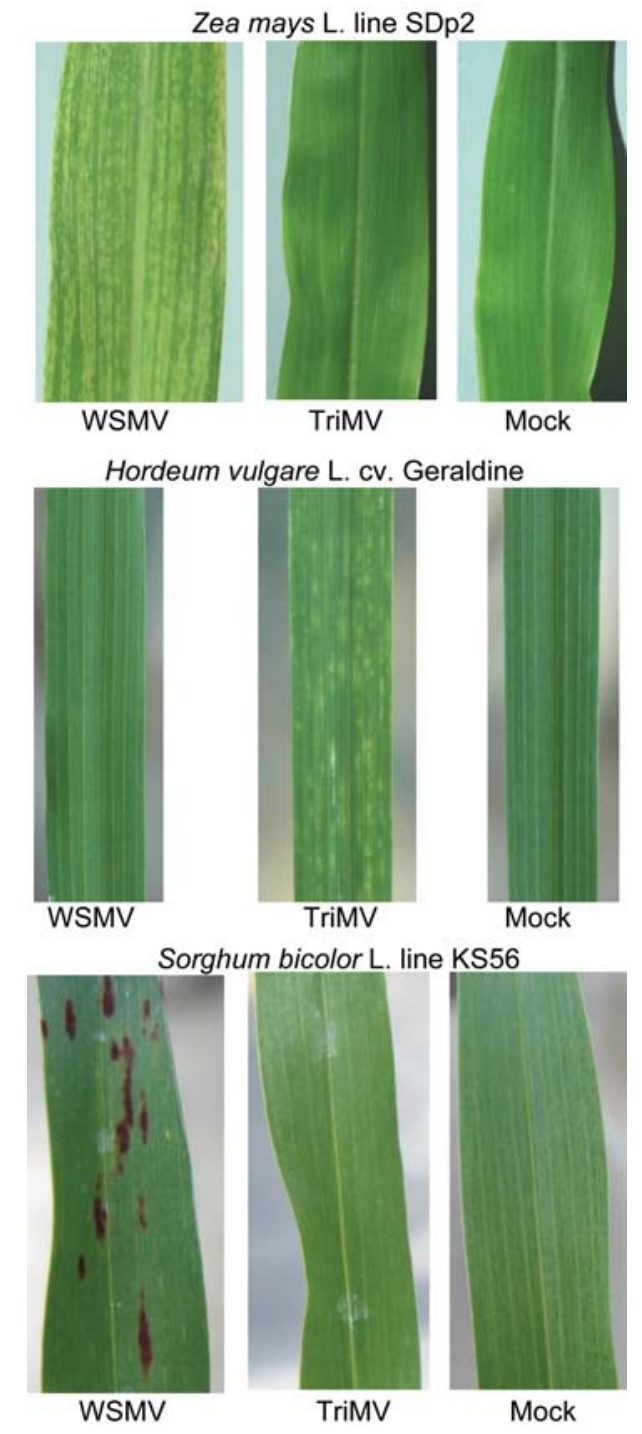

Fig. 1. Differential cereal hosts of Triticum mosaic virus (TriMV) and Wheat streak mosaic virus (WSMV). Expression of symptoms on Zea mays L. line SDp2, Hordeum vulgare L. cv. Geraldine, and Sorghum bicolor L. line KS56 by WSMV and TriMV at 14 days postinoculation. 
-3.7575 (Fig. 3), respectively, which is in good agreement with reported standard curves for other viruses $(15,16,31)$. The realtime PCR assay with WSMV and TriMV primers and probes enabled the detection of as few as five copies of DNA. Amplification plots of PCR results with $18 \mathrm{~S}$ primers and probe had slopes of -3.1617 with $R^{2}=0.9991$ (not shown).

Absolute quantification of WSMV and/or TriMV in single and double infections of wheat cultivars. The numbers of genomic RNA copies of WSMV or TriMV in each treatment at 14 and 28 dpi are presented in Tables 3 and 4 and in Figure 4. The number of genomic RNA copies is equivalent to the number of virus particles present in a given sample because one virus particle encapsidates a single genomic RNA. Our data indicate that more WSMV particles accumulated in all three wheat cultivars at 14 than at $28 \mathrm{dpi}$ at both temperatures except in Mace at $19^{\circ} \mathrm{C}$ (Tables 3 and 5; Fig. 4). At $28 \mathrm{dpi}$, WSMV accumulated in single and double infections of Arapahoe and Tomahawk at both temperatures only at 0.05 - to 0.70 -fold of corresponding infections at 14 dpi (Table 5). By $28 \mathrm{dpi}$, WSMV accumulated in single and double infections of Mace at 19 and 20 to $26^{\circ} \mathrm{C}$ at
A
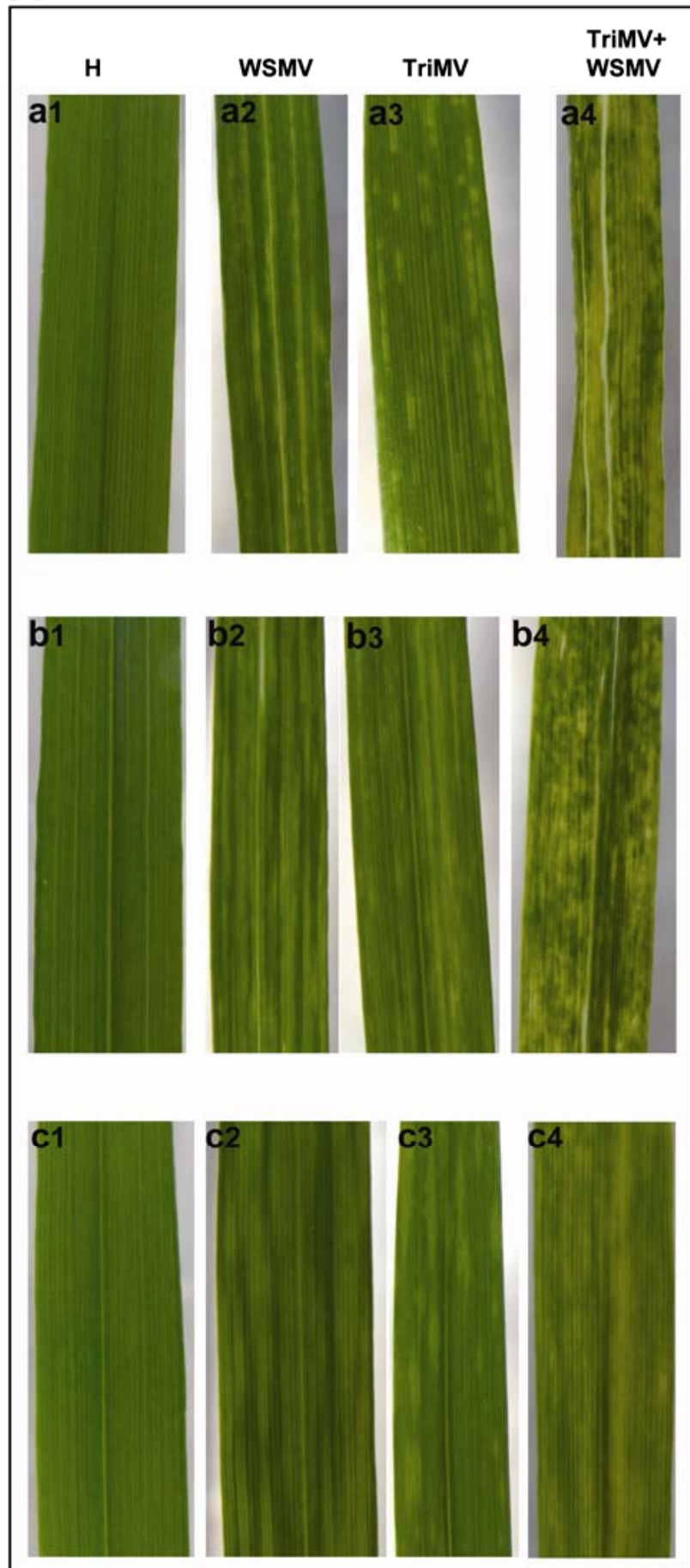

B

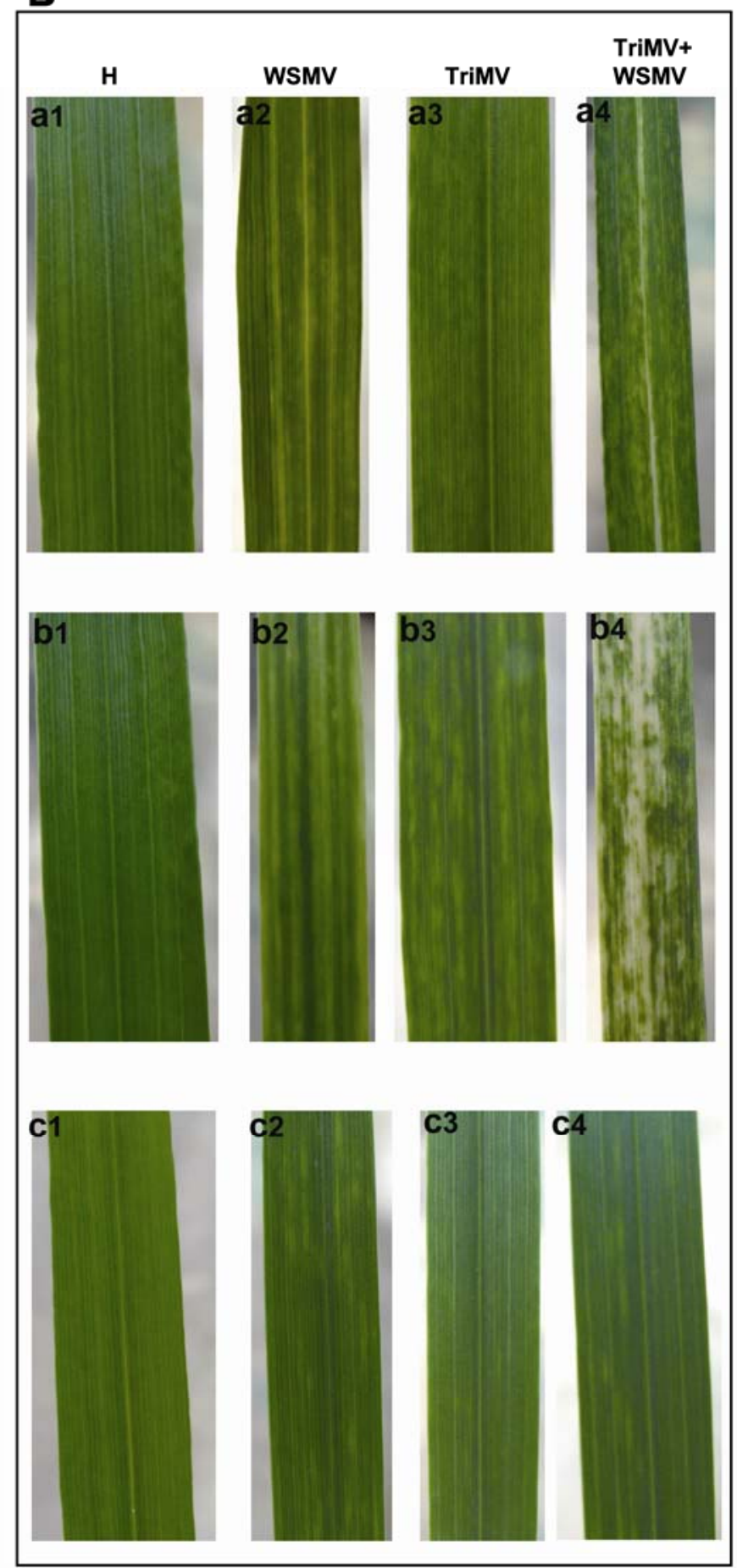

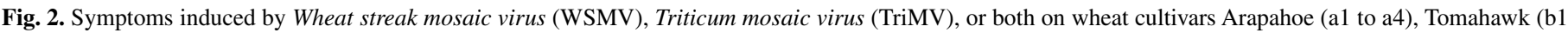

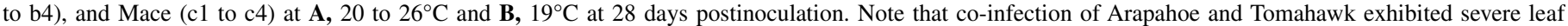

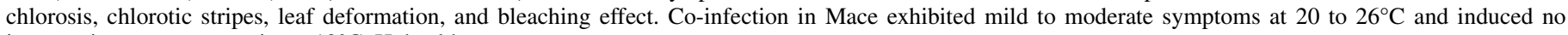
increase in symptom severity at $19^{\circ} \mathrm{C}$. $\mathrm{H}$, healthy. 
10.7- and 1.27-fold and 0.31- and 0.92-fold of corresponding infections at $14 \mathrm{dpi}$, respectively (Table 5). In contrast, more TriMV particles accumulated at 28 than at 14 dpi in all three wheat cultivars at both temperatures, with an increase in accumulation of 1.12- to 143-fold (Tables 4 and 5; Fig. 4). Our data suggest that TriMV replicated poorly at $14 \mathrm{dpi}$ in Mace at both temperatures tested, whereas WSMV replicated efficiently in Mace at 20 to $26^{\circ} \mathrm{C}$ but not at $19^{\circ} \mathrm{C}$. However, by 28 dpi at 20 to $26^{\circ} \mathrm{C}$, TriMV replicated efficiently in Mace and accumulated more virus particles than WSMV (Tables 3 and 4).

At $14 \mathrm{dpi}$, double infections in Arapahoe and Tomahawk at both temperatures resulted in an increase in the number of virus particles accumulated by WSMV and TriMV by 2.2- to 7.4-fold over corresponding single infections (Tables 3 and 4). Double infections at $14 \mathrm{dpi}$ in Mace at 20 to $26^{\circ} \mathrm{C}$ altered TriMV and WSMV accumulation by 2.6 - and 0.5 -fold and at $19^{\circ} \mathrm{C}$ by $0.4-$ and 1.5-fold of corresponding single infections, respectively (Tables 3 and 4). Even though double infections at $14 \mathrm{dpi}$ in Mace resulted in a 2.6-fold increase in TriMV accumulation at 20 to $26^{\circ} \mathrm{C}$ and a 1.5 -fold increase in WSMV accumulation at $19^{\circ} \mathrm{C}$, both viruses replicated poorly in these treatments. However, at 20 to $26^{\circ} \mathrm{C}$, WSMV replicated efficiently in Mace by $14 \mathrm{dpi}$ but the titer of WSMV in doubly infected plants decreased by $50 \%$ over single infections, and there was no visual evidence of disease synergism at $14 \mathrm{dpi}$.

Co-infection with WSMV resulted in an increase in titers of TriMV (1.4- to 2.7-fold) in Arapahoe, Tomahawk, and Mace at $28 \mathrm{dpi}$ at both temperatures tested, except for Mace at $19^{\circ} \mathrm{C}$, where TriMV accumulated only to a titer of 0.2 -fold relative to single infection (Table 4). By $28 \mathrm{dpi}$, the number of WSMV particles accumulated in doubly infected Arapahoe and Tomahawk at $19^{\circ} \mathrm{C}$ was increased by 2.2 - and 1.3 -fold, respectively; however, at 20 to $26^{\circ} \mathrm{C}$, WSMV accumulated only at 0.5 -fold of corresponding single infections (Table 3 ). WSMV accumulation increased in co-infections with TriMV at 28 dpi by 1.6 -fold in Mace at 20 to $26^{\circ} \mathrm{C}$ with mild to moderate symptoms. However, at $19^{\circ} \mathrm{C}$, WSMV accumulated in doubly infected plants only to 0.2-fold of singly infected plants (Table 3).

\section{DISCUSSION}

WSMV and TriMV widely infect wheat in the Great Plains (4). Because these two viruses are naturally transmitted by wheat curl mites $(20,21)$, it is likely that wheat could be naturally co-infected with both viruses. In this study, we found several differential hosts between TriMV and WSMV under experimental conditions which can be used to individually isolate each virus from mixed infections. The differential hosts also will be useful for diagnosis of WSMV and TriMV. Additionally, we examined the interaction between TriMV and WSMV in three wheat cultivars under two different environmental conditions, and found that co-infection resulted in cultivar-specific disease synergism with an increase in the titer of both viruses.

We found differential synergistic interactions between WSMV and TriMV, two distinct potyvirid species, in wheat cultivars Arapahoe, Tomahawk, and Mace. Many synergistic interactions have been reported in the literature between two unrelated viruses $(1,2,7,17,27,30)$. Disease synergism occurred in doubly infected (WSMV+TriMV) Arapahoe and Tomahawk cultivars with extensive leaf deformation, leaf bleaching, and stunting at 19 and 20 to $26^{\circ} \mathrm{C}$ by $14 \mathrm{dpi}$ that were not evident with single infections. In contrast, only mild to moderate synergism was evident in doubly infected Mace at 20 to $26^{\circ} \mathrm{C}$ by 28 dpi but no increase in symptom severity was seen at $14 \mathrm{dpi}$. Failure of synergism to become evident by $14 \mathrm{dpi}$ in doubly infected Mace at 20 to $26^{\circ} \mathrm{C}$ could be due to asymmetrical accumulation of co-infecting viruses, in which WSMV replicated 34-fold more efficiently than TriMV. This suggests that concentrations of individual viruses in mixed infections should reach the threshold level in order to elicit synergistic interaction. Single or double infections of Mace at a low temperature $\left(19^{\circ} \mathrm{C}\right)$ elicited mild symptoms with only a few chlorotic streaks at 14 and 28 dpi. Wheat cv. Mace was reported to be resistant to WSMV (8) and this is certainly true at $19^{\circ} \mathrm{C}$, with WSMV accumulation reduced by $>99 \%$ at $14 \mathrm{dpi}$ and reduced by 88 to $95 \%$ at 28 dpi compared with Arapahoe and Tomahawk. Interestingly, Mace was equally resistant to WSMV and TriMV at $19^{\circ} \mathrm{C}$. It is not known if resistance to TriMV is conditioned by the Wsm-1 gene, a closely linked gene, because resistance genes often are found in clusters (23), or at an entirely different locus. However, in this study, we observed that both WSMV and TriMV induced chlorotic streaks or patches on cv. Mace at 20 to $26^{\circ} \mathrm{C}$, accumulating $\approx 50 \%$ of virus particles compared with Arapahoe and Tomahawk.

Co-infection of two unrelated viruses often affects the concentration of both viruses or selectively affects the concentration of only one virus. To examine differences in viral titers of WSMV and TriMV, we developed a real-time RT-PCR method for absolute quantification of virus particles for both WSMV and
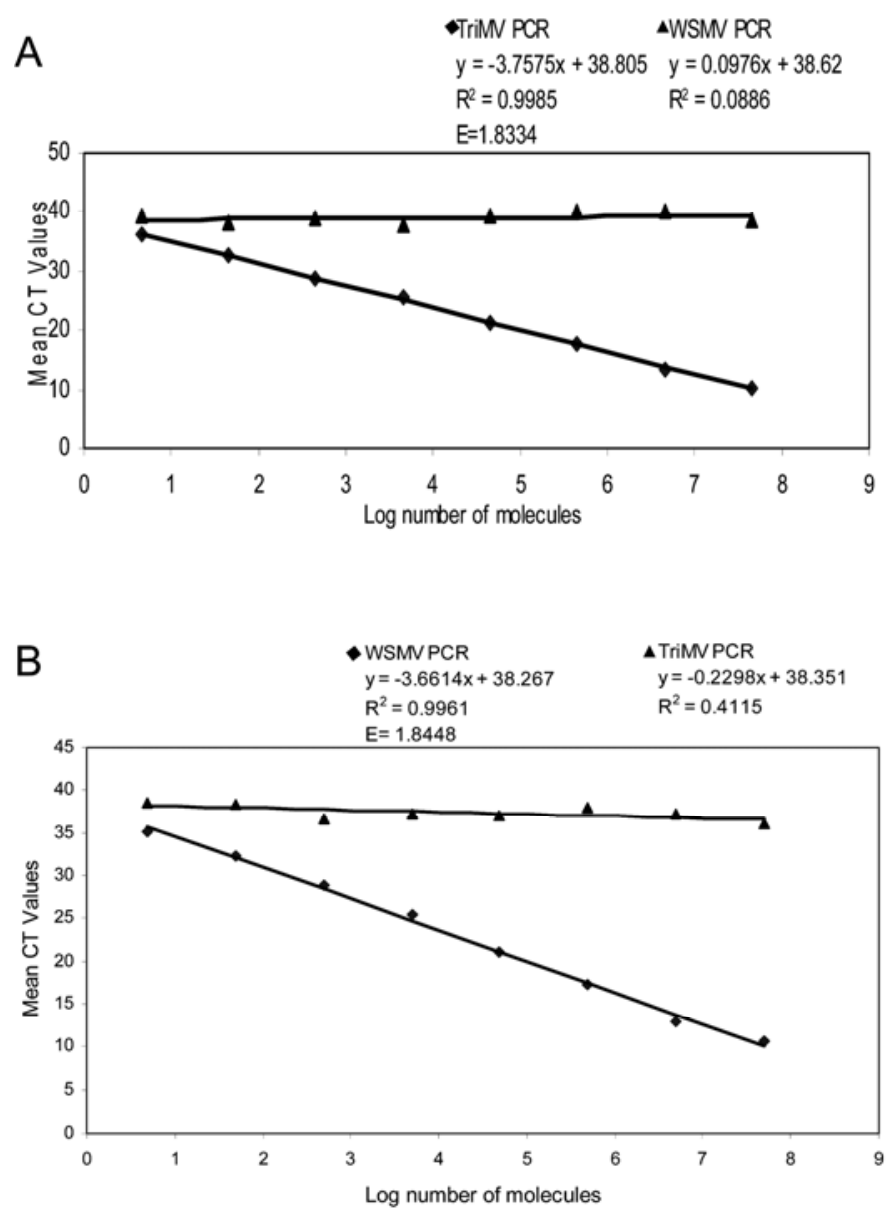

Fig. 3. Preparation of standard curves with 10 -fold serial dilutions of agarosegel-isolated polymerase chain reaction (PCR) fragments of A, Triticum mosaic virus (TriMV) and B, Wheat streak mosaic virus (WSMV) using real-time PCR with TaqMan probes for WSMV and TriMV. Standard curves were generated using linear regression analysis plotting the threshold cycle $(\mathrm{Ct})$ values on the Y-axis versus the logarithm of the starting PCR fragment dilutions containing 4.5 to $4.5 \times 10^{7}$ copies for TriMV and 4.9 to $4.9 \times 10^{7}$ copies for WSMV on the $\mathrm{X}$-axis. The mean $\mathrm{Ct}$ value of each plotted point was the average $\mathrm{Ct}$ value of four replicates. Correlation coefficient, amplification efficiency, and slope value are indicated for each standard curve. PCR templates of WSMV and TriMV were included in each primer-probe combination. Note that the gel-isolated PCR fragment of WSMV or TriMV yielded high $\mathrm{Ct}$ values with a heterologous primer-probe combination. Only the homologous combination of primer-probe yielded $\mathrm{Ct}$ values in proportion to the concentration of the template in real-time PCR. 
TriMV. Real-time RT-PCR has been used to quantify the virus concentration of several plant RNA viruses $(11,15,16,18)$. Even though the real-time RT-PCR is more sensitive and can detect a few copies of RNA molecules, we do not propose this method for a routine diagnostic purpose of WSMV and TriMV, because excellent serological diagnostic methods are available for these viruses. However, the real-time RT-PCR method is an excellent choice for absolute quantification of virus particles to study virus biology, virus gene expression, and virus-host and virus-vector interactions.

Our data suggest that interaction between WSMV and TriMV in Arapahoe and Tomahawk at 14 dpi was mutually beneficial, because the concentration of individual viruses increased by 2.2to 7.4-fold over single infections in contrast to several earlier reports, where the concentration of one of the co-infecting viruses remained unchanged $(1,2,7,30)$ or was even lowered $(14,31)$. Re- cently, Stenger et al. (27) reported a synergistic increase in the titer of WSMV and Maize chlorotic mottle virus (MCMV) in doubly infected Z. mays L. line SDp2 at 17 dpi. It is possible that increased virus titer in double infections may cause increased vector transmissions because vector transmission of plant viruses, in general, is directly related to virus concentration in the source plants, as shown in double infections of Crinivirus spp. (31). This was further supported by increased infection rate by mite transmissions from doubly infected plants (WSMV plus TriMV) than from singly infected plants of either virus (G. L. Hein, unpublished).

There are two unusual aspects of the interaction between TriMV and WSMV worth noting. For most examples of disease synergism, such as with MCMV and Sugarcane mosaic virusMD-B (7), Potato virus X and Potato virus Y (30), and Cowpea mottle virus and Soybean mosaic virus (2), only one of the viruses

TABLE 3. Absolute quantification of Wheat streak mosaic virus (WSMV) in wheat cultivars in single and double infections with Triticum mosaic virus (TriMV)

\begin{tabular}{|c|c|c|c|c|c|c|c|c|c|}
\hline \multirow[b]{2}{*}{$\begin{array}{l}\text { Conditions }^{\mathrm{b}} \\
\text { Cultivar }\end{array}$} & \multirow[b]{2}{*}{ Infection } & \multicolumn{4}{|c|}{14 days postinoculation } & \multicolumn{4}{|c|}{28 days postinoculation } \\
\hline & & $\begin{array}{l}\text { WSMV probe } \\
(\mathrm{Ct} \pm \mathrm{SE})^{\mathrm{c}}\end{array}$ & $\begin{array}{l}18 \mathrm{~S} \text { probe } \\
(\mathrm{Ct} \pm \mathrm{SE})^{\mathrm{c}}\end{array}$ & $\begin{array}{l}\text { Log copies } \\
(\mathrm{X} \pm \mathrm{SE})^{\mathrm{d}}\end{array}$ & $\begin{array}{c}\text { Fold } \\
\text { change }^{\mathrm{e}}\end{array}$ & $\begin{array}{l}\text { WSMV probe } \\
(\mathrm{Ct} \pm \mathrm{SE})^{\mathrm{c}}\end{array}$ & $\begin{array}{l}18 \mathrm{~S} \text { probe } \\
(\mathrm{Ct} \pm \mathrm{SE})^{\mathrm{c}}\end{array}$ & $\begin{array}{l}\text { Log copies } \\
(\mathrm{X} \pm \mathrm{SE})^{\mathrm{d}}\end{array}$ & $\begin{array}{c}\text { Fold } \\
\text { change }^{\mathrm{e}}\end{array}$ \\
\hline \multicolumn{10}{|c|}{$\mathrm{GH}\left(20-26^{\circ} \mathrm{C}\right)$} \\
\hline \multirow[t]{2}{*}{ Arapahoe } & WSMV & $18.6 \pm 0.12$ & $17.5 \pm 0.08$ & $5.61 \pm 4.38$ & & $19.8 \pm 0.20$ & $19.8 \pm 0.24$ & $5.10 \pm 4.70$ & \\
\hline & WSMV+TriMV & $17.6 \pm 0.08$ & $18.2 \pm 0.04$ & $6.12 \pm 4.79$ & $3.2 * * *$ & $18.5 \pm 0.12$ & $17.9 \pm 0.08$ & $4.81 \pm 4.19$ & $0.5 * * *$ \\
\hline \multirow[t]{2}{*}{ Tomahawk } & WSMV & $19.5 \pm 0.24$ & $18.0 \pm 0.08$ & $5.55 \pm 4.80$ & & $19.0 \pm 0.20$ & $18.9 \pm 0.04$ & $5.06 \pm 4.66$ & \\
\hline & WSMV+TriMV & $17.8 \pm 0.08$ & $18.0 \pm 0.04$ & $6.01 \pm 4.67$ & $2.9 * * *$ & $19.0 \pm 0.08$ & $18.4 \pm 0.16$ & $4.77 \pm 4.16$ & $0.5 \mathrm{~ns}$ \\
\hline \multirow[t]{2}{*}{ Mace } & WSMV & $20.3 \pm 0.16$ & $17.8 \pm 0.16$ & $5.21 \pm 3.91$ & & $20.1 \pm 0.20$ & $18.9 \pm 0.20$ & $4.70 \pm 3.58$ & \\
\hline & WSMV+TriMV & $21.5 \pm 0.33$ & $17.9 \pm 0.08$ & $4.93 \pm 4.36$ & $0.5 * *$ & $19.1 \pm 0.24$ & $18.5 \pm 0.20$ & $4.90 \pm 3.86$ & $1.6^{* *}$ \\
\hline \multicolumn{10}{|l|}{$\mathrm{GC}\left(19^{\circ} \mathrm{C}\right)$} \\
\hline \multirow[t]{2}{*}{ Arapahoe } & WSMV & $20.7 \pm 0.38$ & $18.6 \pm 0.04$ & $5.38 \pm 4.72$ & & $21.4 \pm 0.38$ & $20.2 \pm 0.08$ & $4.79 \pm 4.05$ & \\
\hline & WSMV+TriMV & $18.5 \pm 0.12$ & $17.9 \pm 0.12$ & $5.79 \pm 4.78$ & $2.6 * * *$ & $19.3 \pm 0.20$ & $19.5 \pm 0.16$ & $5.14 \pm 3.93$ & $2.2 * * *$ \\
\hline \multirow[t]{2}{*}{ Tomahawk } & WSMV & $20.8 \pm 0.33$ & $18.5 \pm 0.08$ & $5.33 \pm 4.68$ & & $18.8 \pm 0.24$ & $19.1 \pm 0.29$ & $5.17 \pm 4.15$ & \\
\hline & WSMV+TriMV & $17.7 \pm 0.24$ & $18.4 \pm 0.04$ & $6.20 \pm 5.48$ & $7.4 * * *$ & $18.7 \pm 0.08$ & $19.3 \pm 0.33$ & $5.26 \pm 4.39$ & $1.3 \mathrm{~ns}$ \\
\hline \multirow[t]{2}{*}{ Mace } & WSMV & $29.2 \pm 0.33$ & $18.6 \pm 0.04$ & $2.83 \pm 2.13$ & & $23.1 \pm 0.41$ & $18.9 \pm 0.12$ & $3.86 \pm 3.31$ & \\
\hline & WSMV+TriMV & $29.2 \pm 0.78$ & $18.2 \pm 0.04$ & $2.99 \pm 2.79$ & $1.5 \mathrm{~ns}$ & $26.5 \pm 0.45$ & $19.3 \pm 0.16$ & $3.10 \pm 2.79$ & $0.2 * * *$ \\
\hline
\end{tabular}

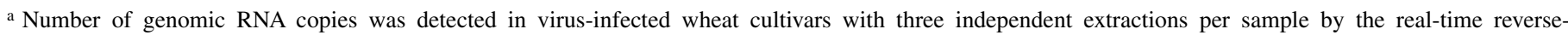
transcription polymerase chain reaction method.

b Conditions: $\mathrm{GH}=$ greenhouse and $\mathrm{GC}=$ growth chamber.

c Average threshold cycle $(\mathrm{Ct})$ and standard error of three independent total RNA extractions with two replicates each.

${ }^{\mathrm{d}}$ Log average number of genomic RNA copies per $2.5 \mathrm{ng}$ of total RNA and log standard error.

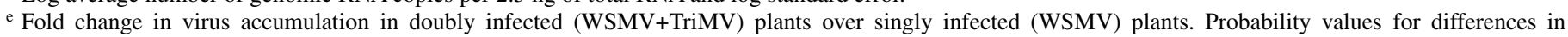
accumulation of virus in doubly infected plants over single infections was calculated using the REST computer program (13); *, **, ***, and ns represent confidence level at 90, 95, and $99 \%$ and not significant, respectively.

TABLE 4. Absolute quantification of Triticum mosaic virus (TriMV) in wheat cultivars in single and double infections with Wheat streak mosaic virus (WSMV)

\begin{tabular}{|c|c|c|c|c|c|c|c|c|c|}
\hline \multirow[b]{2}{*}{$\begin{array}{l}\text { Conditions }{ }^{\mathrm{b}} \\
\text { Cultivar }\end{array}$} & \multirow[b]{2}{*}{ Infection } & \multicolumn{4}{|c|}{14 days postinoculation } & \multicolumn{4}{|c|}{28 days postinoculation } \\
\hline & & $\begin{array}{l}\text { TriMV probe } \\
(\mathrm{Ct} \pm \mathrm{SE})^{\mathrm{c}}\end{array}$ & $\begin{array}{l}\text { 18S probe } \\
(\mathrm{Ct} \pm \mathrm{SE})^{\mathrm{c}}\end{array}$ & $\begin{array}{c}\text { Log copies } \\
(\mathrm{X} \pm \mathrm{SE})^{\mathrm{d}}\end{array}$ & $\begin{array}{c}\text { Fold } \\
\text { change }^{\mathrm{e}}\end{array}$ & $\begin{array}{l}\text { TriMV probe } \\
(\mathrm{Ct} \pm \mathrm{SE})^{\mathrm{c}}\end{array}$ & $\begin{array}{l}\text { 18S probe } \\
(\mathrm{Ct} \pm \mathrm{SE})^{\mathrm{c}}\end{array}$ & $\begin{array}{l}\text { Log copies } \\
(X \pm S E)^{d}\end{array}$ & $\begin{array}{c}\text { Fold } \\
\text { change }^{\mathrm{e}}\end{array}$ \\
\hline \multicolumn{10}{|c|}{$\mathrm{GH}\left(20-26^{\circ} \mathrm{C}\right)$} \\
\hline \multirow[t]{2}{*}{ Arapahoe } & TriMV & $20.9 \pm 0.42$ & $18.5 \pm 0.32$ & $4.93 \pm 4.18$ & & $20.1 \pm 0.33$ & $18.9 \pm 0.04$ & $5.35 \pm 4.69$ & \\
\hline & TriMV+WSMV & $18.4 \pm 0.07$ & $18.2 \pm 0.04$ & $5.44 \pm 3.90$ & $3.3 * * *$ & $18.5 \pm 0.20$ & $17.9 \pm 0.08$ & $5.49 \pm 4.71$ & $1.4 \mathrm{~ns}$ \\
\hline \multirow[t]{2}{*}{ Tomahawk } & TriMV & $20.7 \pm 0.20$ & $18.4 \pm 0.08$ & $4.94 \pm 4.14$ & & $20.6 \pm 0.24$ & $19.1 \pm 0.20$ & $5.30 \pm 4.43$ & \\
\hline & TriMV+WSMV & $18.4 \pm 0.16$ & $18.0 \pm 0.00$ & $5.41 \pm 4.38$ & $2.9 * * *$ & $18.7 \pm 0.12$ & $18.2 \pm 0.20$ & $5.56 \pm 4.55$ & $1.8 * * *$ \\
\hline \multirow[t]{2}{*}{ Mace } & TriMV & $27.2 \pm 0.24$ & $17.7 \pm 0.08$ & $2.99 \pm 2.24$ & & $21.9 \pm 0.53$ & $19.3 \pm 0.12$ & $5.15 \pm 4.65$ & \\
\hline & \multicolumn{9}{|c|}{$\mathrm{GC}\left(19^{\circ} \mathrm{C}\right)$} \\
\hline \multirow[t]{2}{*}{ Arapahoe } & TriMV & $23.1 \pm 0.12$ & $19.9 \pm 0.24$ & $4.80 \pm 4.11$ & & $20.6 \pm 0.29$ & $18.8 \pm 0.16$ & $5.23 \pm 4.39$ & \\
\hline & TriMV+WSMV & $19.2 \pm 0.12$ & $17.9 \pm 0.12$ & $5.10 \pm 3.96$ & $2.2 * * *$ & $19.8 \pm 0.24$ & $19.5 \pm 0.16$ & $5.66 \pm 4.96$ & $2.7 * * *$ \\
\hline \multirow[t]{2}{*}{ Tomahawk } & TriMV & $23.4 \pm 0.37$ & $20.5 \pm 0.33$ & $4.96 \pm 4.48$ & & $20.8 \pm 0.29$ & $20.0 \pm 0.12$ & $5.60 \pm 4.41$ & \\
\hline & TriMV+WSMV & $18.7 \pm 0.12$ & $18.4 \pm 0.04$ & $5.43 \pm 4.13$ & $2.9 * * *$ & $19.0 \pm 0.16$ & $19.3 \pm 0.33$ & $5.83 \pm 5.02$ & $1.7 * *$ \\
\hline \multirow[t]{2}{*}{ Mace } & TriMV & $30.0 \pm 0.12$ & $19.0 \pm 0.08$ & $2.65 \pm 1.74$ & & $26.9 \pm 0.49$ & $19.3 \pm 0.04$ & $3.78 \pm 3.17$ & \\
\hline & TriMV+WSMV & $32.5 \pm 1.67$ & $18.2 \pm 0.04$ & $2.28 \pm 1.83$ & $0.4^{*}$ & $30.2 \pm 0.73$ & $19.3 \pm 0.16$ & $3.02 \pm 2.60$ & $0.2 * * *$ \\
\hline
\end{tabular}

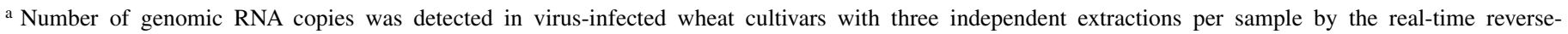
transcription polymerase chain reaction method.

b Conditions: $\mathrm{GH}=$ greenhouse and $\mathrm{GC}=$ growth chamber.

c Average threshold cycle $(\mathrm{Ct})$ and standard error of three independent total RNA extractions with two replicates each.

${ }^{\mathrm{d}}$ Log average number of genomic RNA copies per $2.5 \mathrm{ng}$ of total RNA and log standard error.

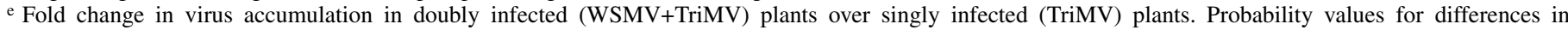
accumulation of virus in doubly infected plants over single infections was calculated using the REST computer program (13); *,**,***, and ns represent confidence level at 90, 95, and $99 \%$ and not significant, respectively. 
show an increase in titer. However, an increase in virus concentration of both interacting viruses and with concomitant increase in disease severity as seen with WSMV and TriMV has also been seen with WSMV and MCMV $(17,27)$. Second, it is rare that two viruses from the same family are synergistic. Synergism between two Crinivirus spp. has been reported (31) and, interestingly, between the potyvirids WSMV and Agropyron mosaic virus as well as between WSMV and Hordeum mosaic virus (22).

The increase in WSMV concentration in single and double infections by $14 \mathrm{dpi}$, followed by a decrease at $28 \mathrm{dpi}$, might be due to initial robustness of WSMV in wheat cultivars. Stenger et al. (27) also reported the reduced levels of WSMV accumulation in doubly infected Z. mays L. line SDp2 at 30 over 17 dpi. In contrast, TriMV concentration was increased progressively at 14 and 28 dpi in single and double infections at both temperatures, suggesting that TriMV may not be as aggressive as WSMV or even milder initially, steadily accumulated over time, and might not have reached maximum concentration even by $28 \mathrm{dpi}$. At present, we have no information on the distribution of WSMV and TriMV in doubly infected wheat cvs. Arapahoe and Tomahawk. However, we can determine this once an infectious cDNA clone of TriMV is developed (an infectious cDNA clone of WSMV is available) by the introduction of two different fluorescent marker proteins into cDNA clones.

The ability to cause disease synergism by WSMV and TriMV in wheat cultivars has several implications in disease management strategies, because both viruses infect wheat naturally with a common vector. Even though cv. Mace was reported as resistant to WSMV, we observed that both WSMV and TriMV could rep-

TABLE 5. Accumulation of Wheat streak mosaic virus (WSMV) and Triticum mosaic virus (TriMV) at 28 days postinoculation (dpi) over $14 \mathrm{dpi}$ in single and double infections of wheat cultivars ${ }^{\mathrm{a}}$

\begin{tabular}{llccccc}
\hline & & \multicolumn{2}{c}{ WSMV fold difference } & & \multicolumn{2}{c}{ TriMV fold difference } \\
\cline { 3 - 4 } \cline { 6 - 7 } Cultivar & Infection & $20-26^{\circ} \mathrm{C}$ & $19^{\circ} \mathrm{C}$ & & $20-26^{\circ} \mathrm{C}$ & $19^{\circ} \mathrm{C}$ \\
\hline Arapahoe & Single & 0.3 & 0.25 & & 2.65 & 2.67 \\
& Double & 0.05 & 0.23 & & 1.12 & 3.27 \\
Tomahawk & Single & 0.33 & 0.7 & & 2.36 & 4.34 \\
& Double & 0.06 & 0.12 & & 1.42 & 2.52 \\
Mace & Single & 0.31 & 10.7 & & 143 & 13.5 \\
& Double & 0.92 & 1.27 & & 76.5 & 5.5 \\
\hline
\end{tabular}

${ }^{\text {a }}$ Fold difference in virus accumulation at 28 over 14 dpi was calculated from Table 3 (for WSMV) and Table 4 (for TriMV).

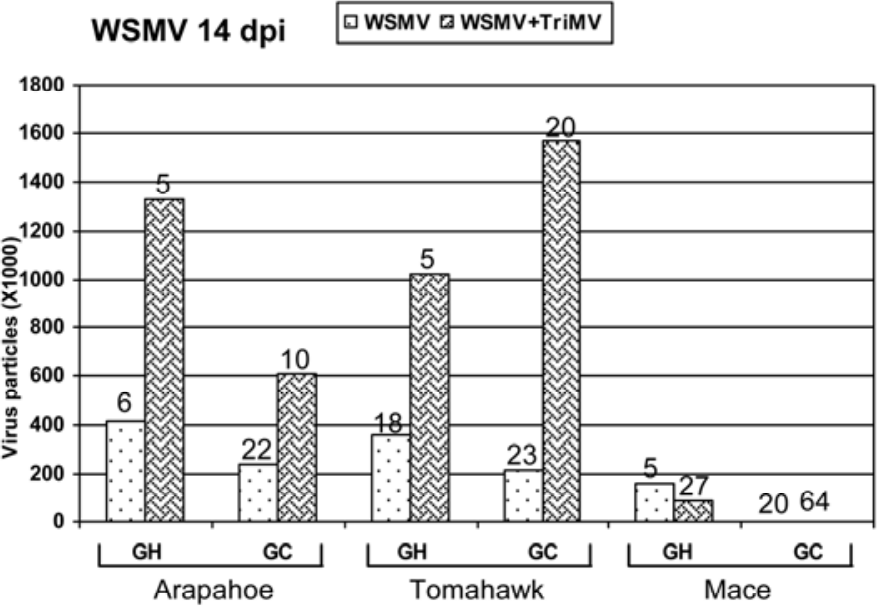

TriMV 14 dpi $\square$ TriMV [ TriMV+WSMV

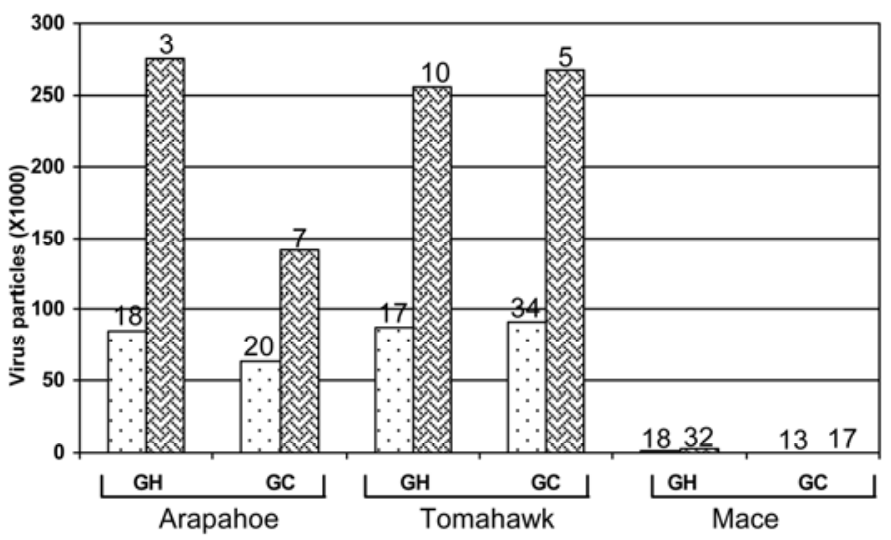

\section{WSMV 28 dpi ¿ WSMV \& WSMV+TriMV}

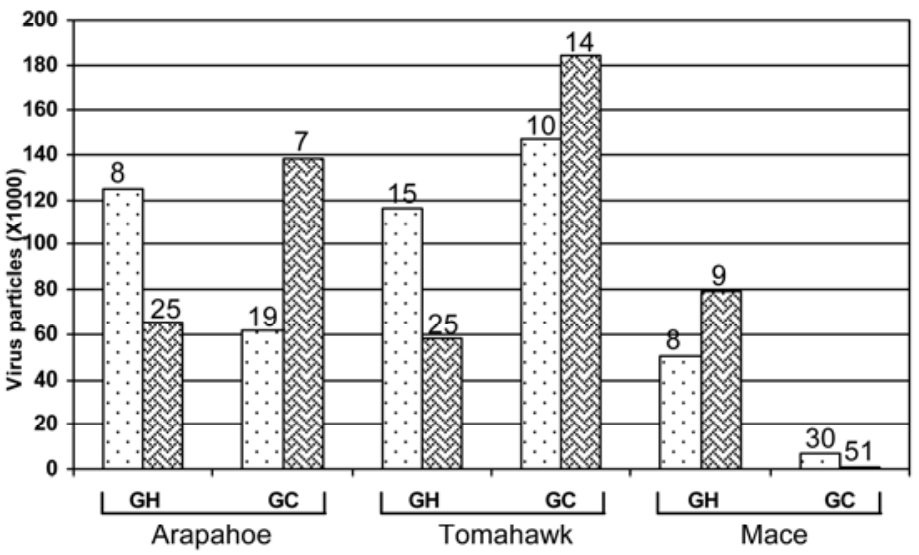

TriMV 28 dpi $\square$ TriMV $\square$ TriMV+WSMV

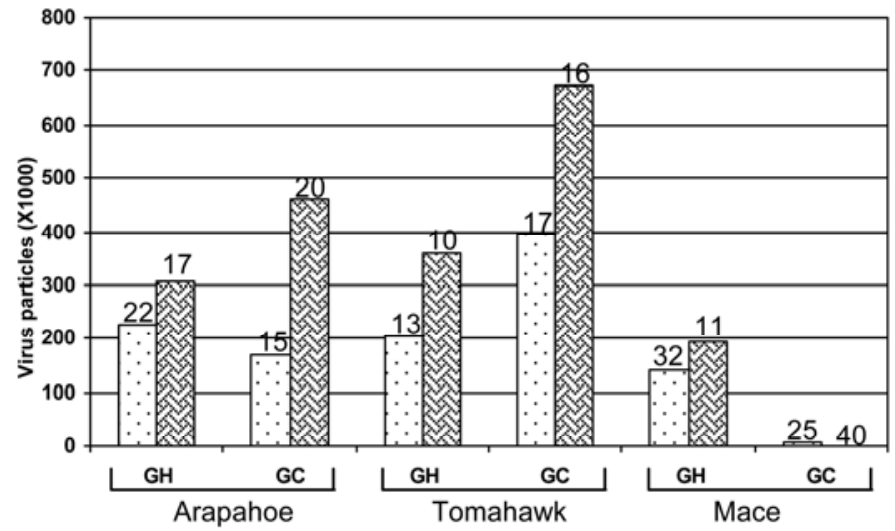

Fig. 4. Absolute quantification of Wheat streak mosaic virus (WSMV) and Triticum mosaic virus (TriMV) in wheat cultivars (Arapahoe, Tomahawk, and Mace) infected with WSMV, TriMV, or both at 14 days postinoculation (dpi) by real-time RT-PCR. Virus-inoculated wheat plants were incubated at $19^{\circ} \mathrm{C}$ in a growth chamber (GC) and at 20 to $26^{\circ} \mathrm{C}$ in a greenhouse (GH). The number of virus particles was detected in virus-infected wheat cultivars with three independent extractions per sample. Bars indicate the number of virus particles times 1,000 with percent standard error (number above the bars) in $2.5 \mathrm{ng}$ of total RNA. Note that double infection resulted in an increase in accumulation of WSMV and TriMV at 14 and 28 dpi in Arapahoe and Tomahawk plants incubated at 19 and 20 to $26^{\circ} \mathrm{C}$ (except WSMV at $28 \mathrm{dpi}$ at 20 to $26^{\circ} \mathrm{C}$ ). In contrast, at 20 to $26^{\circ} \mathrm{C}$, WSMV accumulation decreased in double infections in Arapahoe and Tomahawk over single infections at $28 \mathrm{dpi}$. In Mace at $19^{\circ} \mathrm{C}$, WSMV and TriMV accumulated to low levels in single or double infections at 14 and 28 dpi whereas, at 20 to $26^{\circ} \mathrm{C}$ in double infections, TriMV accumulation increased at 14 and $28 \mathrm{dpi}$ and WSMV accumulation decreased at 14 dpi but increased at 28 dpi over single infections. 
licate efficiently at higher temperatures $\left(20\right.$ to $\left.26^{\circ} \mathrm{C}\right)$ but, at low temperatures, Mace was, in fact, resistant to both WSMV and TriMV infections as evidenced by accumulation of much less virus compared with Arapahoe and Tomahawk. The delayed mild to moderate symptoms in Mace at 20 to $26^{\circ} \mathrm{C}$ and tolerance or resistance at low temperatures could allow a wheat crop to escape the effects of viral infections at the young susceptible stage and maintain greater disease tolerance as plants mature.

The observed synergism between WSMV and TriMV implies that, under field conditions, the potential exists for greater damage and, therefore, yield loss if a wheat crop is co-infected by both viruses compared with infection by either virus alone. Based on the results in this study, damage and yield loss caused by coinfection by both viruses are likely to be more severe in susceptible cultivars. Therefore, cultivar selection will be an important management strategy for the WSMV/TriMV disease complex in wheat. Symptoms in co-infected cvs. Arapahoe and Tomahawk were more severe at 20 to 26 than at $19^{\circ} \mathrm{C}$ and generally increased with days postinoculation, implying that, under field conditions, detrimental effects from co-infection of a wheat crop by both viruses are likely to be exacerbated by early planting and warmerthan-normal temperatures during the fall (for autumn-sown wheat) and during the growing season (for both autumn-sown and spring-sown wheat).

\section{ACKNOWLEDGMENTS}

Mention of proprietary or brand names are necessary to report factually on available data; however, the USDA neither guarantees nor warrants the standard of the product, and the use of the name by USDA implies no approval to the exclusion of others that also may be suitable. We thank C. J. Aldrich for excellent technical assistance, S. Gowda for critical reading of the manuscript, and $\mathrm{M}$. Burrows for the generous gift of barley cultivar seed used in this investigation.

\section{LITERATURE CITED}

1. Anderson, E. J., Kline, A. S., Morelock, T. E., and McNew, R. W. 1996. Tolerance to blackeye cowpea mosaic potyvirus not correlated with decreased virus accumulation or protection from cowpea stunt disease. Phytopathology 80:847-852.

2. Anjos, J. R., Jarlfors, U., and Ghabrial, S. A. 1992. Soybean mosaic potyvirus enhances the titer of two comoviruses in dually infected soybean plants. Phytopathology 82:1022-1027.

3. Brakke, M. K. 1987. Virus disease in wheat. Pages 585-603 in: Wheat and Wheat Improvement, 2nd ed. E. G. Heyne, ed. American Society of Agronomy, Crop Science Society of America, Soil Science Society of America, Madison, WI.

4. Burrows, M., Franc, G., Rush, C., Blunt, T., Ito, D., Kinzer, K., Olson, J., O'Mara, J., Price, J., Tande, C., Ziems, A., and Stack, J. 2009. Occurrence of viruses in wheat in the Great Plains region 2008. Plant Health Progress doi:10.1094/PHP-2009-0706-01-RS

5. Choi, I. R., French, R., Hein, G. L., and Stenger, D. C. 1999. Fully biologically active in vitro transcripts of the eriophyid mite-transmitted wheat streak mosaic tritimovirus. Phytopathology 89:1182-1185.

6. French, R., and Stenger, D. C. 2004. Wheat streak mosaic virus. Pages 602-604 in: Viruses and Virus Diseases of Poaceae. H. Lapierre and P. Signoret, eds. INRA Editions, Paris.

7. Goldberg, K.-B., and Brakke, M. K. 1987. Concentration of maize chlorotic mottle virus increased in mixed infections with maize dwarf mosaic virus, strain B. Phytopathology 77:162-167.

8. Graybosch, R. A., Peterson, C. J., Baenziger, P. S., Baltensperger, D. D., Nelson, L. A., Jin, Y., Kolmer, J. A., Seabourn, B. W., French, R. C., and Hein, G. L. 2009. Registration of Mace hard red winter wheat. J. Plant Regist. 3:51-56.
9. Kassanis, B. 1963. Interactions of viruses in plants. Adv. Virus Res. 10:219-255.

10. Muller, P. Y., Janovjak, H., Miserez, A. R., and Dobbie, Z. 2002. Processing of gene expression data generated by quantitative real-time RT-PCR. BioTechniques 32:1372-1377.

11. Osman, F., Leutenegger, C., Golino, D., and Rowhani, A. 2007. Real-time RT-PCR (TaqMan) assays for the detection of Grapevine leafroll associated viruses 1-5 and 9. J. Virol. Methods 141:22-29.

12. Pfaffl, M. W. 2001. A new mathematical model for relative quantification in real-time RT-PCR. Nucleic Acids Res. 29:e45.

13. Pfaffl, M. W., Horgan, G. W., and Dempfle, L. 2002. Relative expression software tool (REST) for group-wise comparison and statistical analysis of relative expression results in real-time PCR. Nucleic Acids Res. 30:e36.

14. Poolpol, P., and Inouye, T. 1986. Enhancement of Cucumber mosaic virus multiplication by Zucchini yellow mosaic virus in double infected cucumber plants. Ann. Phytopathol. Soc. Jpn. 52:22-30.

15. Ruiz-Ruiz, S., Moreno, P., Guerri, J., and Ambrós, S. 2007. A real-time RT-PCR assay for detection and absolute quantification of Citrus tristeza virus in different plant tissues. J. Virol. Methods 145:96-105.

16. Saponari, M., Manjunath, K., and Yokomi, R. K. 2008. Quantitative detection of Citrus tristeza virus in citrus and aphids by real-time reverse transcription-PCR (TaqMan). J. Virol. Methods 147:43-53.

17. Scheets, K. 1998. Maize chlorotic mottle machlomovirus and wheat streak mosaic rymovirus concentrations increase in the synergistic disease corn lethal necrosis. Virology 242:28-38.

18. Schneider, W. L., Sherman, D. J., Stone A. L., Damsteegt, V. D., and Frederick, R. D. 2004. Specific detection and quantification of Plum pox virus by real-time fluorescent reverse transcription-PCR. J. Virol. Methods 120:97-105.

19. Seifers, D. L., Martin, T. J., Harvey, T. L., Fellers, J. P., and Michaud, J. P. 2009. Identification of the wheat curl mite as the vector of Triticum mosaic virus. Plant Dis. 93:25-29.

20. Seifers, D. L., Martin, T. J., Harvey, T. L., Fellers, J. P., Stack, J. P., RybaWhite, M., Haber, S., Krokhin, O., Spicer, V., Lovat, N., Yamchuk, A., and Standing, K. G. 2008. Triticum mosaic virus: A new virus isolated from wheat in Kansas. Plant Dis. 92:808-817.

21. Slykhuis, J. T. 1955. Aceria tulipae Keifer (Acarina: Eriophyidae) in relation to spread of wheat streak mosaic virus. Phytopathology 45:116-128.

22. Slykhuis, J. T., and Bell, W. 1966. Differentiation of Agropyron mosaic, wheat streak mosaic, and a hitherto unrecognized Hordeum mosaic virus in Canada. Can. J. Bot. 44:1191-1208.

23. Smith, S. M, Pryor, A. J., and Hulbert, S. H. 2004. Allelic and haplotypic diversity at the rp1 rust resistance locus of maize. Genetics 167:1939-1947.

24. Stenger, D. C., and French, R. 2004. Functional replacement of Wheat streak mosaic virus HC-Pro with the corresponding cistron from a diverse array of viruses in the family Potyviridae. Virology 323:257-267.

25. Stenger, D. C., Hall, J. S., Choi, I.-R., and French, R. 1998. Phylogenetic relationships within the family Potyviridae: Wheat streak mosaic virus and brome streak mosaic virus are not members of the genus Rymovirus. Phytopathology 88:782-787.

26. Stenger, D. C., Hein, G. L., Gildow, F. E., Horken, K. M., and French, R. 2005. Plant virus HC-Pro is a determinant of eriophyid mite transmission. J. Virol. 79:9054-9061.

27. Stenger, D.C., Young, B. A., Qu, F., Morris, T. J., and French, R. 2007. Wheat streak mosaic virus lacking helper component-proteinase is competent to produce disease synergism in double infections with Maize chlorotic mottle virus. Phytopathology 97:1213-1221.

28. Taiwo, M. A., Kareem, K. T., Nsa, I. Y., and Hughes, J. D., 2007. Cowpea viruses: Effect of single and mixed infections on symptomatology and virus concentration. Virol. J. 2007, 4:95

29. Tatineni, S., Ziems, A. D., Wegulo, S. N., and French, R. 2009. Triticum mosaic virus: A distinct member of the family Potyviridae with an unusually long leader sequence. Phytopathology 99:943-950.

30. Vance, V. B. 1991. Replication of potato virus X RNA is altered in coinfections with potato virus Y. Virology 182:486-494.

31. Wintermantel, W. M., Cortez, A. A., Anchieta, A. G., Gulati-Sakhuja, A., and Hladky, L. L. 2008. Co-infection by two criniviruses alters accumulation of each virus in a host-specific manner and influences efficiency of virus transmission. Phytopathology 98:1340-1345. 